University of Wollongong

Research Online

Faculty of Law, Humanities and the Arts Papers (Archive)

Faculty of Arts, Social Sciences \& Humanities

$1-1-2016$

The wondrous (Baroque) gender revolution, or the rise and fall of the empire of fairies

Luis Gomez Romero

University of Wollongong, Igromero@uow.edu.au

Follow this and additional works at: https://ro.uow.edu.au/lhapapers

Part of the Arts and Humanities Commons, and the Law Commons

Research Online is the open access institutional repository for the University of Wollongong. For further information contact the UOW Library: research-pubs@uow.edu.au 


\title{
The wondrous (Baroque) gender revolution, or the rise and fall of the empire of fairies
}

\author{
Abstract \\ The essay which follows is mainly concerned with how the history of ideas on norms, justice and power is \\ shaped by the stories we tell and how we tell them. It specifically addresses the normative codes \\ introduced into Western imaginaries by the raise of the literary fairy tale in France during the late \\ seventeenth century. In both their oral and literary varieties, wonder fairy tales (Zaubermärchen or contes \\ merveilleux) have constantly charted and undermined the contours of our cultural and political realities by \\ escaping or retreating from them. ${ }^{3}$ The merveilleux genre allowed the first writers of fairy tales to act \\ ideologically by embedding their own views on social conditions and conflicts into their narratives, while \\ they interacted at the same time with each other and with past writers and storytellers in the public \\ sphere. ${ }^{4}$ The question of the history and meaning of the first literary fairytales hence reflects the \\ paradoxical cultural and political realities of the Baroque, which is the cultural and historical context in \\ which they were created. In other words, the baroque aesthetic strategies deployed in the first literary fairy \\ tales mirror specific political and juridical tensions which, I will argue, continue to relate to our \\ understanding of the world today.

\section{Disciplines} \\ Arts and Humanities | Law

\section{Publication Details} \\ L. Gomez Romero, 'The wondrous (Baroque) gender revolution, or the rise and fall of the empire of fairies' \\ in M. Leiboff \& D. Carpi(eds), Fables of the Law: Fairy Tales in a Legal Context (2016) 49-81.
}


Luis Gómez Romero

\section{The Wondrous (Baroque) Gender}

Revolution, or the Rise and Fall of the Empire of Fairies

"[...] hat die Menschheit einmal ihren Erzähler verloren so hat sie auch ihre Kindschaft verloren."1

Peter Handke/Richard Reitinger/Wim Wenders:

Der Himmel über Berlin

\section{Introduction: The ambivalent pleasures of baroque ${ }^{2}$ imagination}

The essay which follows is mainly concerned with how the history of ideas on norms, justice and power is shaped by the stories we tell and how we tell them. It specifically addresses the normative codes introduced into Western imaginaries by the raise of the literary fairy tale in France during the late seventeenth century. In both their oral and literary varieties, wonder fairy tales (Zaubermärchen or contes merveilleux) have constantly charted and undermined the contours of our cultural and political realities by escaping or retreating from them. ${ }^{3}$ The merveilleux genre allowed the first writers of fairy tales to act ideologically by embedding their own views on social conditions and conflicts into their narratives, while they interacted at the same time with each other and with past writers and storytellers in the public sphere. ${ }^{4}$ The question of the history and meaning of the first literary fairy tales hence reflects the paradoxical cultural and political realities of the Baroque, which is the cultural and historical context in which they were created. In other words, the baroque aesthetic strategies deployed in the first literary fairy tales mirror specific political and juridical ten-

1 “[...] once humanity has lost its storyteller, it has also lost its childhood's bonds ." Unless otherwise indicated, all translations are my own.

2 I will capitalize the term "Baroque" whenever I use it as a noun, and I will write it in lower case letters when used adjectivally.

3 Lewis Carl Seifert, Fairy Tales, Sexuality, and Gender in France 1690-1715: Nostalgic Utopias (Cambridge: Cambridge University Press, 1996), 1.

4 Jack Zipes, Fairy Tales and the Art of Subversion: The Classical Genre for Children and the Process of Civilization ( $2^{\text {nd }}$ edition, New York/London: Routledge, 2006), 3. 
sions which, I will argue, continue to relate to our understanding of the world today.

Theorising about the Baroque implies settling the previous and complex matter of defining it. What do we mean when we use such a term? Are we speaking of a precise moment in the history of art or, on the contrary, are we alluding to a lasting and universal aesthetic style and, even more, to a philosophical mood and modus? In other words, has the Baroque transcended seventeenthcentury Europe? This dilemma is far from being just a matter of convoluted erudition which can be easily dismissed or quickly analyzed in a footnote commentary. The work of the main theorists of the Baroque - from Heinrich Wölfflin to Walter Benjamin, Eugenio d'Ors, José Antonio Maravall, Gilles Deleuze or Bolivar Echeverría - has been consistently troubled by these questions. ${ }^{5}$

The aesthetic debate about and around the Baroque can be illustrated by reference to the opposed approaches to this concept respectively championed by Eugenio D’Ors and José Antonio Maravall. D’Ors claims that the Baroque is a "cultural style" whose key feature - the negation of classicism - transcends historical contexts in such a way that it embeds the possibility of being "reborn" in different times and places by translating its "inspiration" into "new forms." ${ }^{6}$ The problem with this approach is its inherent conceptual promiscuity: D’Ors finds baroque forms both in Prehistory "among the savages" (Barocchus archaicus) and in contemporaneous popular cultures (Barocchus vulgaris). ${ }^{7}$ Maravall, on the contrary, argues that the Baroque is merely "a defined period in the history of some European countries" whose limits can approximately be established from 1600 to $1680 .{ }^{8}$ Maravall's narrow periodization, however, simply brings to light the problem of defining the Baroque since it is clearly inaccurate, for example, in relation to baroque music. ${ }^{9}$

5 William Egginton, The Theater of Truth: The Ideology of (Neo)Baroque Aesthetics (Stanford: Stanford University Press, 2010), 69.

6 Eugenio D’Ors, Lo Barroco [1935] (Madrid: Tecnos, 1993), 74.

7 D’Ors, Lo Barroco, $93 \mathrm{ff}$.

8 Maravall concedes that it is possible to "establish some relations between external, purely formal elements of the seventeenth-century European baroque and elements present in very different epochs in unrelated cultural areas." He regards the endeavours for establishing such connections, however, as "witty riddles" which purely express some "pleasant arbitrariness." José Antonio Maravall, La Cultura del Barroco: Análisis de una Estructura Histórica [1975] (Barcelona: Ariel, 2012), 21-23.

9 See, for example, Thomas Christensen, "Genres of Music Theory, 1650-1750" in Towards Tonality: Aspects of Baroque Music Theory, ed. Thomas Christensen et al (Leuven: Leuven University Press, 2007): 9-39; and Nikolaus Harnoncourt, Baroque Music Today: Music as Speech; 
Walter Benjamin makes evident the substantive dilemma that lies behind the obvious tension between D'Ors and Maravall's approaches to the Baroque. Benjamin advocates the necessity of a transdisciplinary study of the Baroque, capable of critically surmounting the historical and epistemological constraints imposed on artworks by both the philosophy of art and the history of art. In his view, aesthetic concepts such as "Renaissance" or "Baroque" do not aim at making "the similar identical," but "they effect a synthesis between extremes."10 This sort of aesthetic concepts thus aim at abstracting rules to assess individual artworks by comparing them to the "outstanding representatives" (hervorragender Vertreter) of each genre or epoch, which supposedly set in the aesthetic "laws of art" (Kunstgesetze) which apply to each and every work. ${ }^{11}$ On this basis Benjamin claims that, from a conceptual perspective, historical types and epochs risk to dissolve the aesthetic structures or forms of the artwork by denying their "irreducible multiplicity" (unreduzierbare Vielheit) for the sake of an illusory unity of art. $^{12}$

Deleuze overcomes the epistemological perplexities around the definition of the Baroque that Benjamin pointed out. For the purposes of this essay, I will endorse Deleuze's reading of the Baroque not as an "essence," but as an "operative function" (fonction opératoire) or "trait" in the historical development of Western thought. ${ }^{13}$ Deleuze considers the Baroque as a trope which can be used to designate a current of thought that, radiating through time, has expressed an "attempt to reconstitute a classical reason" by dividing the divergences in our reality "into as many worlds as possible," and also by transforming incompossibilities - that is, the incapability of joint existence of diverging realities - into "as many possible borders between worlds." 14

I do not vindicate, of course, any sort of originality in such a theoretical choice. During the last three decades a good number of authors have argued that the general aesthetic trends of the late twentieth and early twenty first centuries, instead of being called postmodern, should be more accurately labelled

Ways to a New Understanding of Music, ed. Reinhard G. Pauly, trans. Mary O'Neill (Portland: Amadeus Press, 1995), $24 \mathrm{ff}$.

10 Walter Benjamin, Ursprung des Deutschen Trauerspiels [1928], in Gesammelte Schriften, eds. Rolf Tiedemann and Hermann Schweppenhäuser (Frankfut am Main: Suhrkamp, 2013), I-1:221.

11 Benjamin, Ursprung des Deutschen Trauerspiels, 223.

12 Benjamin, Ursprung des Deutschen Trauerspiels, 223.

13 Gilles Deleuze, Le Pli: Leibniz et le Baroque (Paris: Minuit, 1988), 5.

14 Deleuze, Le Pli, 111. 
as neobaroque. ${ }^{15}$ I must clarify, however, that though this is undoubtedly an appealing thesis which has shown itself quite useful for understanding the basic traits of our present cultural landscape, I am not interested in exploring the recurrence of baroque aesthetic patterns, but rather in delving into the permanence - coterminous with the development of modernity - of what William Egginton has compellingly called the baroque "problem of thought." ${ }^{16}$ This problem refers to the cultural continuity of the Baroque's obsession with discerning paths of truthful knowledge among "the ephemeral and deceptive appearances" of the world we live in, that is to say, "the reduction of whatever difference exists between those appearances and the world as it is." 17

A problem of thought is not simply a philosophical problem. Problems of thought, according to Egginton, affect or unsettle "an entire culture in the largest possible sense, that permeates its very foundations and finds expression in its plastic art, in its stories and performances, in its philosophy as well as in its social organization and politics." ${ }^{18}$ I will therefore claim that some traits of our modern conceptions of justice and social order are rooted in baroque political realities, concepts and controversies. ${ }^{19}$ There is a specifically baroque way of being modern that has unfolded from the seventeenth century to the present in some regions of world (for example, in Latin America ${ }^{20}$ ) and, beyond those regions, in some particular political matters (such as gender roles). In this sense, the permanence of the Baroque as a problem of thought is remarkably evident in the literary fairy tales that were published in France between the last decade of the seventeenth century and the first decade of the eighteenth century that is, the marvelous stories which are historically situated at the basis of the institutionalization of the fairy tale as a literary genre -, whose cultural influence

15 See, for example, Omar Calabrese, L'Età Neobarroca (Roma: Laterza, 1987) and Angela Ndalianis, (Neo)Baroque Aesthetics and Contemporary Entertainment (Cambridge, Massachusetts: MIT Press, 2004).

16 Egginton, The Theater of Truth, 1-9.

17 Egginton, The Theater of Truth, 2.

18 Egginton, The Theater of Truth, 1.

19 This claim corresponds mutatis mutandis with Walter Benjamin's thesis that modernity is founded upon a sense of melancholy for the loss of tradition and the stability it offers, and that the aesthetic sign and origin of this melancholy is the Baroque. See Benjamin, Ursprung des Deutschen Trauerspiels, 317 ff; and Christine Buci-Glucksmann, La Raison Baroque: De Baudelaire a Benjamin (Paris: Galile, 1984), 58.

20 See Bolívar Echeverría, La Modernidad de lo Barroco (Ciudad de México: Era, 1998), 161 ff. 
has stretched to our days mainly through the works of Charles Perrault (16281703). ${ }^{21}$

Lewis C. Seifert has adequately categorized fairy tales as one of "the most marginal and the most central of all cultural forms."22 While, on the one hand, fairy tales are hardly taken seriously nowadays by the wide public (and a substantial number of academics and critics) because a series of widespread prejudices hold them as somewhat simplistic, preposterous and childish narratives; on the other hand, fairy tales are also powerful normative narratives to the extent in which they establish social and cultural patterns of personal initiation, becoming and maturity. Fairy tales are no strangers to the symbolic force of myths, ${ }^{23}$ which are in turn foundational elements of what Robert Cover calls nomos (after the Greek word vópos, meaning "convention," "custom" or "law"), that is, the narrative universe of norms we live in or, in other terms, the discursive site where we constantly define, negotiate and resist the notions of right and wrong, lawful and unlawful, just and unjust. "This nomos," writes Cover, "is as much 'our world' as is the physical universe of mass, energy, and momentum." ${ }^{24}$ Its constitutive narratives are resources in signification that enable us to carry out diverse normative actions: for example, "to submit, rejoice, struggle, pervert, mock, disgrace, humiliate, or dignify." ${ }^{25}$

The construction of meaning within the domain of nomos depends heavily on storytelling. In this sense, fairy tales are sources of law. ${ }^{26}$ Desmond Manderson has neatly expressed the importance of narratives for the settlement of normative orders when he observes that while "[s]tories do not prescribe behaviour" as "they do not lay down laws for us," they instead "inscribe behaviour" as "they

21 Lewis Carl Seifert identifies two major "waves" or "vogues" of publication of fairy tales from 1690 to 1789, the first extending until 1715 and the second from 1730 to 1758 . See Fairy Tales, Sexuality, and Gender in France 1690-1715, 5. Jack Zipes establishes a slightly different periodization of the French fairy-tale vogue: a) the experimental salon fairy tale, 1690-1703; b) the Oriental tale, 1704-1720; and c) the conventional and comical fairy tale, 1721-1789. See Zipes, When Dreams Came True: Classical Fairy Tales and Their Tradition ( $2^{\text {nd }}$ ed, New York/London: Routledge, 2007), 41. This essay addresses what both authors consider the first wave of French literary fairy tales.

22 Seifert, Fairy Tales, Sexuality, and Gender in France 1690-1715, 1.

23 Mircea Eliade, Aspects du Mythe [1963], (Paris: Gallimard, 2011), $237-248$.

24 Robert Cover, "Nomos and Narrative," Harvard Law Review 97.1 (1983): 4-68, 4-5.

25 Cover, "Nomos and Narrative," 8.

26 I have thoroughly discussed elsewhere the assimilation of several types of narratives into the sources of law through legal pluralism. See Luis Gómez Romero, "Republicanism Meets (Dystopian) Faërie: Harry Potter and the Institutional Disaster," in Cultural Legal Studies: Law's Popular Cultures and the Metamorphosis of Law, eds. Cassandra Sharp and Marett Leiboff (Abingdon/ New York: Routledge, 2015): 274-295, 279-282. 
lay down ways of being in us."27 Regardless the hegemonic disenchantment of Western culture, we are still prone to become the kind of persons that fairy tales teach us to be: bold or obedient, courteous or clever, generous or cautious. Fairy tales may have been gradually reduced from offshoots of the sacred myths to nursery trifles and amusing lies, but such trifles and lies continue to rule our lives today.

Literary fairy tales, contrarily to the common belief, were not first and originally created for children. It was not until the late eighteenth and early nineteenth centuries that fairy tales were published for children, and even then they were frequently considered unsuitable for the youngest members of the elites because of their "coarse" roots in the folklore of the lower classes. ${ }^{28}$ In seventeenth-century France, these stories were intended for adult readers. The works of the first generation of French conteurs and conteuses - Marie-Catherine d'Aulnoy, Charles Perrault, Catherine Bernard, Marie-Jeanne L'Héritier de Villandon, Henriette-Julie de Murat or Charlotte-Rose Caumont de la Force among many others ${ }^{29}$ - were actually written and enjoyed in worldly aristocrat salons. The literary fairy tales (contes de fées) were primarily a form of social amusement within the courtly society which consisted in diverting and playing with a myth, a legend or a folktale until it was transformed into a real préciosité, that is, a witty and astonishing little piece of literary art. ${ }^{30}$

The contes de fées that we now retell as bedtime stories for children reflect the aspirations and anxieties of the age in which they were written. This is the obvious point of departure for determining the appropriate method to uncover their role in the configuration of contemporary nomoi. The first stage of this method, as Edward Said suggests, consists in focusing "as much as possible on individual works, to read them first as great products of the creative or interpretative imagination." 31 The second stage depends then on showing them as

27 Desmond Manderson, "From Hunger to Love: Myths of the Source, Interpretation and Constitution of Law in Children's Literature," Law and Literature 15.1 (2003): 87-141, 90.

28 Jack Zipes, Fairy Tale as Myth: Myth as Fairy Tale (Lexington: The University Press of Kentucky, 1994), 14.

29 Other important contributors to the first vogue of French fairy tales were Louise d'Auneuil, Catherine Bédacier Durand, Jean-Paul Bignon, François-Timoléon de Choisy, François de la Mothe-Fénelon, Eustache Le Noble, Jean de Mailly, François-Agustin de Moncrif, Paul-François Nodot and Jean de Préchac. See Patricia Hannon, Fabulous Identities: Women's Fairy Tales in Seventeenth Century France (Amsterdam: Rodopi, 1998), 13 and Seifert, Fairy Tales, Sexuality, and Gender in France 1690-1715, 5-6.

30 For a brief characterization of literary préciosités, see Jean Rousset, La Littérature de l'Âge Baroque en France: Circé et le Paon (Paris: José Corti, 1954), 240-242.

31 Edward Said, Culture and Imperialism (New York: Vintage, 1994), xxii. 
part of the relationship between culture and the historical-political context in which they were created, because even though authors are not "mechanically determined by ideology, class or economic history," they are necessarily "very much in the history of their societies, shaping and shaped by that history and their social experience in different measure." 32

The language and themes of the first literary fairy tales hence fluctuate in a precarious equilibrium between nostalgia for the fading hegemony of nobility which found itself increasingly displaced and disenfranchised after the consolidation of Absolutism -, and radical utopian hope of truthful deliverance driving towards a different future beyond religious orthodoxy and absolutist politics. ${ }^{33}$ In such a context, the conteurs and conteuses not only reproduced and reinforced the codes and values of correct demeanor and established power that were current in the courtly society, but they also incorporated subversive elements of the oral folktales that inspired them or introduced new challenges to the ruling paradigms of behavior and taste.

The primal French literary fairy tales therefore lay bare the contradictions of the civilizing processes we have inherited from the Baroque. The fluidity between spatial or conceptual levels or strata (as in the painterly technique of trompe l'oeil) is what distinctively characterizes them as baroque artworks. ${ }^{34}$ The early conteurs and counteuses structured their narratives upon an aesthetic strategy that José Antonio Maravall designated as "the technique of incompleteness" (técnica de lo inacabado). ${ }^{35}$ According to Maravall, baroque artists typically drew the recipients of the artwork into it by an illusory depth that entails a promise of fulfilment beyond the surface, always just beyond grasp. ${ }^{36}$ My intention is to cast some light over the paradoxical form of political agency - which is both privileged in the deployment of imaginative resources and tightly constrained by established conventions at the same time - that results from this aesthetic strategy in order to trace its impact on contemporary Western nomoi.

I have divided the essay in three sections to achieve this goal. The first section addresses the epistemological problem of baroque representations and its nexus to the merveilleux - considered as a genre of estranged literature - as a

32 Said, Culture and Imperialism, xxii, 14. Raymond Williams' concept of structures of feeling that is, the lived experience of culture and society at a particular time and place - reverberates in this methodological approach. See Marxism and Literature [1977] (Oxford: Oxford University Press, 2009), 132.

33 Seifert, Fairy Tales, Sexuality, and Gender in France 1690-1715, 12-18.

34 Egginton, The Theater of Truth, 16-17.

35 Maravall, La Cultura del Barroco, $331 \mathrm{ff}$.

36 Maravall, La Cultura del Barroco, 344-350. 
means for structuring subversive normative discourses through multiple layers of narrative and meaning. The second section is focused on the specific subversive narrative strategies deployed by the female writers who significantly contributed to the first vogue of literary fairy tales. The third section briefly traces the genealogy of hegemonic gendered codes of behavior and civilite that are rooted in the fairy tales of Charles Perrault. This will set the argument to conclude that the time has come for us to retell these stories by exploiting the fairy tales' magic not to simply make their spell work out, but rather to unmake some of their (unjust) workings.

\section{Marvellous Knowledge: the (baroque) epistemology of fairies}

The problem of thought that underlies the Baroque is related to the predicaments of representation. Modern Western epistemologies have been persistently anxious about the adequacy of our knowledge in relation to a world that we can only perceive through our flawed senses and understanding. It is a wellknown fact that, in the eighteenth century, Immanuel Kant stirred a Copernican revolution in Western thought against the perplexities of both empiricism (via David Hume) and rationalism (via Gottfried Wilhelm Leibniz) by systematizing an epistemology based upon the acknowledgement of the complex nexus between the perception of the external world (which provides us with those things we sense) and a priori categories of knowledge built in our mind (for example, the forms of time and space, which process the information about the external world prior to its actual perception and organize it in such a way that its comprehension is rendered possible to us). ${ }^{37}$

Kant also maintained that whatever that comes to our cognition through sensibility can only be thought as a representation of things as they appear. On the contrary, things-in-themselves (Dinge an sich) do not depend on their appearance to our sensibility. ${ }^{38}$ Drawing from ancient philosophical terminology, Kant called phenomenon (from the Greek фaıvó $\mu \varepsilon v o \varsigma$, i.e., 'apparent') anything that can be apprehended by, or is an object of, the physical senses ${ }^{39}$, in order to differentiate it from noumenon, that is, a posited object or event as it is

37 See Immanuel Kant, Kritik der reinen Vernunft [1781/1787], ed. Jens Timmermann (Hamburg: Felix Meiner, 1956).

38 Kant, Kritik der reinen Vernunft, $83 \mathrm{ff}$.

39 Kant, Kritik der reinen Vernunft, 300-302. 
known in itself and as it is known to be through pure intellect (voũ $).{ }^{40}$ In Kant's view, human beings can make sense out of phenomena in several ways, but can never directly know the noumena. Human minds may attempt to correlate in useful and (loosely) accurate ways with the order and structure of the various aspects of the universe, but cannot achieve an absolute grasp of "things-in-themselves" (noumena). Nevertheless, humans can actually infer the extent to which thoughts correspond with things-in-themselves (noumena) by observing the manifestations of those things that can be sensed (phenomena). ${ }^{41}$

Kant thus set up the modern distinction between appearances and the things they represent. The Baroque aesthetic style, in contrast, denies this distinction, relying instead on a playful intertwinement and confrontation of appearances. Heinrich Wölfflin, for example, characterizes what he calls the malerisch (a German term which can be translated as 'painterly' or 'picturesque') style in baroque architecture in the following way: "the severe style of architecture makes its effect by what it is or its corporeal substance; while painterly [baroque] architecture acts through what it appears to be: an illusion of movement." ${ }^{42}$ In other words, by blurring spaces and contours for creating a cinematic impression, the malerisch style merges the represented object with its representation. Walter Benjamin similarly defines baroque allegories not as a conventional representation of some expression, but as an expression of convention (Ausdruck der Konvention)..$^{43}$ This means that convention - which is an artificial and formal usage in itself - is signified or expressed in baroque allegories. Baroque representations are hence open to embody other representations, as reflections in infinity mirrors.

The problem of thought enclosed in this aesthetic style can be dissected in two epistemological postulates that William Egginton has configured as major and minor baroque strategies. The major baroque strategy, according to Egginton, "assumes the existence of a veil of appearances, and then suggests the possibility of a space opening just beyond those appearances where truth resides."44 In painting and architecture this strategy corresponds to the baroque techniques of trompe l'oeil, anamorphosis or malerisch. This primary structure of baroque representation - which proved to be extremely useful for reinforcing the interests

40 Kant, Kritik der reinen Vernunft, 304-305.

41 Kant, Kritik der reinen Vernunft, $305 \mathrm{ff}$.

42 Heinrich Wölfflin, Renaissance und Barock: Eine Untersuchung über Wesen und Entstehung des Barockstils in Italien [1888] (Basel: Schwabe, 1965), $27-28$.

43 Benjamin, Ursprung des Deutschen Trauerspiels, 351.

44 Egginton, The Theater of Truth, 3. 
of the ruling classes at the height of the historical Baroque ${ }^{45}$ - is, however, all the same open to subversive possibilities. The minor baroque strategy indeed radicalizes the major strategy by ironically affirming representation as the only reality in order to "remind us that we are always, at any level, involved with mediation." 46

Egginton draws our attention to a couple of masterworks of the Spanish Golden Century of baroque literature to demonstrate the interplay between both strategies: on the one hand, Fuente Ovejuna, a play by Félix Lope de Vega, to illustrate the major strategy; on the other hand, an entremés (interlude) titled El Retablo de las Maravillas (The Stage of Wonders), by Miguel de Cervantes Saavedra, to illustrate the minor strategy. ${ }^{47}$ Fuente Ovejuna - which was first published in Madrid in 1619- is based upon an actual historical incident. Fernán Gómez de Guzmán - a commander (comendador) of the Order of Calatrava grievously mistreated the residents of Fuente Ovejuna, who banded together and killed him around 1476. In Lope de Vega's theatrical script, when the villagers rise up against Gómez de Guzmán, they do so in the name of the honor of both men and women after he rapes a peasant woman and tries to impose his jus primae noctis on another on her wedding night. ${ }^{48}$ When a magistrate sent by King Ferdinand II of Aragon arrives at the village to investigate, the villagers, even under the pain of torture, respond to the question "Who killed the commander?" only by saying "Fuente Ovejuna did it." 49

According to Egginton, within the context of Hapsburg Spain, the spectators would certainly know they were watching a play, but it could not escape them that they too were commoners. ${ }^{50}$ If the commoners in the play had honor,

45 Maravall, La Cultura del Barroco, $127-171$.

46 Egginton, The Theater of Truth, 6. Egginton acknowledges that this conceptual category is indebted to Gilles Deleuze and Félix Guattari's theorization of a minor literature, which is defined by the "deterritorialization" of a major language by using it from a marginalized or minoritarian position. See Kafka: Pour une Littérature Mineure (Paris: Minuit, 1975) $29 \mathrm{ff}$.

47 Egginton, The Theater of Truth, 5-8.

48 This is how Lucrecia, one of the women who Gómez de Guzmán tried to force, calls other women to take part in the popular uprising: “Será bien que solos ellos / de esta hazaña el honor gocen, / pues no son de las mujeres / sus agravios los menores?” (Is it appropriate that only men / enjoy the honor of this feat / if women's grievances / are not inconsiderable?) Félix Lope de Vega, Fuente Ovejuna [1619], in El Caballero de Olmedo y Fuente Ovejuna, eds. Antonio Prieto y Maria Grazia Profeti (Barcelona: RBA Editores, 1994) 3.1826-1829. The term jus primæ noctis refers to the medieval custom that allegedly allowed the feudal lord to share the wedding bed with his dependent peasants' brides.

49 Lope de Vega, Fuente Ovejuna, 3.2359-2385.

50 Egginton, The Theater of Truth, 5. 
then the spectators should also participate in this moral trait. In other words, the play intends to stage, behind the appearances of theatrical representation, the supposed realities of the honor of the commoners. The play was colored in this way by a series of normative (moral, political and legal) assumptions that provided the commoners who attended the theater the illusory gratification of perceiving themselves as subjects of rights or protections against the land-owning elites.

Fuente Ovejuna thus deploys the basic structure of baroque representation. This is not, however, the entire story. The minor baroque strategy, rather than accepting the presupposition of two opposing levels - a representation (or appearance) and a reality independent of that representation - undermines our ability to make this distinction in the first place. ${ }^{51}$ In Cervantes' El Retablo de las Maravillas, for example, two swindlers - the man Chanfalla and the woman Chirinos -, persuade the authorities of a village to let them put on a paid performance of their marvelous puppet show as part of a wedding celebration. ${ }^{52}$ Chanfalla warns the people, however, that in order to see his wonderful show they must have been born within the bounds of marriage (therefore excluding bastards) and be Old Christians (that is, cristianos viejos, which means that they must have no trace of Jewish or Muslim blood in their ancestry). ${ }^{53}$

The performance consists merely of the verbal evocation by the tricksters of a succession of wondrous appearances, since they have no puppets at all. The villagers, ashamed at seeing nothing and fearful of betraying themselves to be New Christians, at first pretend that they see the various acts. Soon it is evident, however, that they delude themselves into believing that they do see the wonders that Chanfalla and Chirinos describe. ${ }^{54}$ A quartermaster then arrives and, after demanding - as is his legal right - that the commoners give up their homes for the king's troupes, he openly confesses that he cannot see the show. ${ }^{55}$ The spell of the swindlers' fiction, unfortunately, is not broken by this intruder, for the villagers immediately accuse him of being "ex illis" (that is, "from them," meaning that he is a bastard or has Jewish or Moorish blood). ${ }^{56}$ The entremés ends with the enraged quartermaster stabbing the villagers and Chanfalla and Chirinos congratulating each other on the success of their deception.

51 Egginton, The Theater of Truth, 6.

52 Miguel de Cervantes Saavedra, El Retablo de las Maravillas [1615], in Obras Completas, ed. Angel Balbuena Prat (Madrid: Aguilar, 1967) 580.

53 Cervantes, El Retablo de las Maravillas, 580-581.

54 Cervantes, El Retablo de las Maravillas, 582-583.

55 Cervantes, El Retablo de las Maravillas, 584.

56 Cervantes, El Retablo de las Maravillas, 585. 
The major strategy posits a separation between a representation and the reality hidden behind it in order to smuggle certain presuppositions into yet another representation that it will try to present as reality itself. The minor strategy, on the contrary, ironically affirms representation as the only reality. ${ }^{57}$ Using the major strategy, Lope de Vega surreptitiously introduces the claim to honor among commoners into the realities that Fuente Ovejuna pretends to represent. Cervantes, in contrast, forced the commoners who watched his entremés to confront the reality of their honor as nothing but a play they were putting on for one another. When the villagers try to import the honor and purity they were representing to one another into the real world of the soldiers' demands on their homes, their so-called honor got treated like the fantasy it really was. The minor strategy, as Egginton notes, hence focuses on the concrete reality of mediation itself and produces a mode of thought that does not deny the real, but focuses on how representations are themselves real even while they try to make us believe that their reality, the reality in which we live, is always somewhere else. ${ }^{58}$

There is a close relationship between the baroque major strategy and Kantian philosophy. Kant's epistemology and the major strategy share a similar uneasiness with the connections between the world as it is given to us, the world as we - intellectually and morally - compose it, and our role in the transition from one to the other. Historians and philosophers alike have traditionally stressed the differences between the baroque major epistemological strategy and Kantian critique, neglecting what they have in common: the problem of a subject of knowledge whose cognitive faculties are limited or somehow determined by appearances.

This common ground renders the supernatural characters and settings that are an intrinsic feature of the seventeenth-century French fairy tales not only a product of baroque aesthetic strategies, but also cultural forerunners of the Enlightenment's discourses on knowledge, morality and politics. In other words, exploring the context in which literary fairy tales emerged can help uncover the conditions of possibility for the Enlightenment, that is, the cultural transfor-

57 Egginton, The Theater of Truth, 6.

58 Egginton, The Theater of Truth, 8. Deleuze apparently envisioned an analogous account of this baroque strategy as he states that "the essence of the Baroque entails neither falling into nor emerging from illusion but rather realizing something in illusion itself." See Le Pli, 170. 
mations that contributed to make the Enlightenment a thinkable or conceivable intellectual project. ${ }^{59}$

Kant's proximity to the baroque major strategy, for example, is most evident in his ethics. ${ }^{60}$ In Kant's view, we can only be acting morally if we are acting autonomously, that is, free from the heteronomous influences of our experience of the world of appearances. ${ }^{61}$ The only way we can hope to act morally, then, is to purge the maxims of our actions of any reference to non-moral incentives to do one's duty, such as individual desires. Hence the categorical imperative (kategorischer Imperativ): act only in such a way that the maxim of your actions can be made into a universal law ("handle nur nach derjenigen Maxime, durch die du zugleich wollen kannst, daß sie ein allgemeines Gesetz werde"). ${ }^{62}$ Kant's certainty that we inhabit a world of appearances leads him to conclude that the only possibility for human freedom is a radical submission to the moral law, which takes the form of an imposition of universal conformity on the maxims of our actions. ${ }^{63}$

In Kantian ethics, the appearances embedded in our feelings and desires must always pay ultimate deference to the reality of moral duty. The merveilleux narratives that compose literary fairy tales similarly rearrange the world and emancipate us from the tyranny of deceptive appearances, but they do this by suspending the rules and constraints of reality. The narratives of the first literary fairy tales thus oscillate between the major and minor baroque strategies. The tension between both strategies in these fairy tales can be brought to light by simply outlining the aesthetic conventions that determine the merveilleux. Tzvetan Todorov has conveniently defined the merveilleux by contrasting it with fantastic literature. Todorov observes that, whereas fantastic literature expresses a moment of hesitation between a natural (immanent, empirical, or scientific) and a supernatural (transcendent, intuitive, or magical) explanation of narrative events, marvelous literature openly assumes the abnormal as normal. According to Todorov, fairy tales are among the most widely known literary expressions of the merveilleux. The fairy tale is therefore "nothing but a variety of the marvelous

59 On the historiographical requirements for a genealogy of the Enlightenment, see Dan Edelstein, The Enlightenment: A Genealogy (Chicago and London: The University of Chicago Press, 2010) $16-18$.

60 Egginton, The Theater of Truth, 90.

61 Immanuel Kant, Grundlegung zur Metaphysik der Sitten [1785], in Gesammelte Schriften (Berlin: Georg Reimer, 1903), 4:406.

62 Kant, Grundlegung zur Metaphysik der Sitten, 421.

63 Egginton, The Theater of Truth, 92. 
in which supernatural events do not surprise us: neither the hundred years slumber, nor the wolf that talks, nor the magical gifts of fairies." 64

It must be noted, however, that the French conteurs and conteuses of the seventeenth century did not directly invent the characteristic wondrous and magical elements of their literary fairy tales. Their work represents an appropriation of a particular storytelling tradition related to the oral wonder tale - Zaubermärchen or conte merveilleux - which was developed throughout Europe in many different forms during the Middle Ages. What is specifically original in their tales is the incipient secularized context (that is, the very waking of the Kantian separation between phenomena and noumena) in which they wrote them. In order to cast its magical spell over its audience, the merveilleux requires a previous disenchantment of reality. The historical conditions that determined the emergence of the merveilleux as a literary genre are therefore similar to those that Darko Suvin identifies at the origins of fantastic literature:

Fantastic fiction is entirely - and more clearly than other genres - a creature of history: everybody (from Walter Scott on) agrees that it is not thinkable before overriding mythological or religious belief suffers an epochal political breakdown, as a consequence of which some of its aspects and elements become available for fictional manipulation. Its beginnings can be dated - at various times in various countries - to a time when the bourgeois laicizing cleavage into natural vs. supernatural begins to dominate at least in the literate classes, and yet the alternative to realism is no longer straightforward allegory. ${ }^{65}$

How did all this come about? In the cultural context of the late seventeenth century, some members of the French literate classes were aware of the exhaustion of the principle of vraisemblance that ruled the aesthetic conventions of the time. The term vraisemblance, despite the fact that it is often translated to English as verisimilitude or plausibility, was quite far from indicating the likeness or resemblance of the artwork to truth, reality, or fact. Vraisemblance was actually an ideological outcome of the ut pictura poesis ${ }^{66}$ representational system that dominated artistic practices in early modern Europe. This system favored analogy or allegory over direct reference. Imitation ( $\mu$ í $\mu \sigma \iota \varsigma)$ was considered artful only when it rendered both a recognizable and distant world. On this aesthetical premise, vraisemblance was understood at least in three different ways: first, as a refusal of the moral chaos of history for the praise "of an ideal world in

64 Todorov, Tzvetan. Introduction à la Littérature Fantastique [1970] (Paris: Seuil, 2005), 59. 65 Darko Suvin, “Considering the Sense of 'Fantasy' or 'Fantasy Fiction': An effusion,” Extrapolation 41.3 (2000): 209-247, 216. See also Juan Herrero Cecilia, Estética y Pragmática del Relato Fantástico (Cuenca: Universidad de Castilla-La Mancha, 2000) $51 \mathrm{ff}$.

66 "As is painting so is poetry." 
which right always triumphs over wrong;" second, as the "codification" of what was publicly taken for "good or common sense"; and third, as a real attempt of perfecting "individual species" in accordance with a "true original."

At first glance, the three facets of vraisemblance do not necessarily preclude the merveilleux. An artwork was vraisemblable not because it reproduced reality in a referential sense, but because of its adequacy to a restricted set of ideological parameters. The merveilleux, however, rules out vraisemblance as it transforms conditions which are contrary to "facts" into the "facts" themselves. In the case of the primal contes de fées, vraisemblance was transgressed and undermined by the self-conscious and playful use of supernatural characters and scenarios, which counteracted the reduction of verisimilitude to the ethical, social and political codes accepted by the dominant public opinion. ${ }^{68}$

Lewis C. Seifert argues that the merveilleux in the French contes de fées implies "an estrangement of empirically defined reality" since "it is either an exaggeration of the real or an assertion of the impossible." 69 We can thus take the analysis of the cultural contribution of the literary fairy tale to the modern structure of normative discourses one last step further by establishing its nexus to the cognitive horizons of estranged literature. Darko Suvin distinguishes between two main forms of literary prose: the naturalistic that painstakingly reproduces textures, superficies and relations which can be authenticated by our senses; and the estranged that displaces a given event or object, situating it in an imaginary frame outside the known reality. ${ }^{70}$ By means of estranged representation, we are able to recognize an object or a situation but, at the same time, we lose our familiarity with it. In other words, estranged narratives require their readers to adopt some degree of detachment from their own social, political and cultural contexts. In this sense, utopias, science fiction and fairy tales can be properly classified as estranged narratives. ${ }^{71}$

67 Seifert, Fairy Tales, Sexuality, and Gender in France 1690-1715, 26-27.

68 Seifert, Fairy Tales, Sexuality, and Gender in France 1690-1715, 32.

69 Seifert, Fairy Tales, Sexuality, and Gender in France 1690-1715, 23.

70 Suvin, Darko, "On the poetics of the science fiction genre," College English 34.3 (1972): 372-383, 374-375.

71 Suvin originally dismissed fairy tales as escapist narratives without any cognitive content (see "On the poetics of the science fiction genre," 375-376). He later reconsidered his assessment of the fantastic and marvelous literary genres under the influence of Jack Zipes, thus accepting that " $[t]$ he divide between cognitive (pleasantly useful) and non-cognitive (useless) does not run between S[cience] F[iction] and fantastic fiction but inside each -though in rather different ways and different proportions, for there are more obstacles to liberating cognition in the latter." Suvin hence claims that the wondrous worlds created by fairy tales "can be seen as a spread of possibilities between the poles of a subversion bringing out the social repressed [...] 
The merveilleux radicalizes the use of fantasy - which Rosemary Jackson has famously defined as a "literature of desire"72 - as it aims both to the displacement and transfiguration of our given historical world. Utopia therefore holds strong ties with Fäerie. Our desire to create secondary and alternative realities arises, to a large extent, "from our dissatisfaction with the primary world," as W. H. Auden once stated. ${ }^{73}$ In similar terms, the surrealist writer Pierre Mabille implicitly acknowledges this fundamental discontent at the roots of the merveilleux when he defines this genre as a "poetic and passionate tension" that, on one hand, synthesizes "the struggle of freedom against everything that threatens to reduce, destroy or mutilate it" and, on the other hand, expresses the perennial human craving for "exceeding the imposed limits" towards "a greater beauty, a greater power" and "a greater joy."74

In sum, the early French literary fairy tales, which were nourished in the beaux esprits of baroque aesthetic strategies, fostered in turn an embryonic enlightened ethos within the boundaries of their marvelous realms. As Nancy L. Canepa observes, the marvelous fairy tale is an ideal vehicle of expression for the utopian openness of baroque sensibilities, upon which everything - be it the individual or the society - "risks transformation into everything else, and any given reality can assume a multitude of appearances."75

\section{L'Empire de Féerie as a fairy manifesto}

I have already established that the French writers of the late seventeenth century did not invent the magic tale. They neither strictly conceived the literary fairy tale. Two Italian writers, Giovanni Francesco Straparola and Giambattista Basile, had previously published a couple of collections of fairy tales: respectively, Le Piacevoli Notti (1550-1553) ${ }^{76}$ and Lo Cunto de li Cunti (1634). ${ }^{77}$ The first genera-

and a use [of imagination] that reaffirms and 'naturalizes' repression" (see "Considering the Sense of Fantasy,” 211 and 220). Though I do not agree with Suvin's rigid distinction between "useful" and "useless" literary works, I find his theses about estranged fiction quite suggestive. 72 Rosemary Jackson, Fantasy: The Literature of Subversion (New York: Methuen, 1981), 3. 73 W. H. Auden, Secondary Worlds (London: Faber and Faber, 1968), 51.

74 Pierre Mabille, Le Merveilleux (Paris: Les Éditions des Quatre Vents, 1946), 68-69.

75 Nancy L. Canepa, From Court to Forest: Giambattista Basile's 'Lo cunto de li cunti' and the Birth of the Literary Fairy Tale (Detroit: Wayne State University Press, 1999), 60.

76 Giovan Francesco Straparola, Le Piacevoli Notti [1550-1553] (Bari, Laterza, 1927).

77 Giambattista Basile, Lo Cunto de li Cunti, overo Lo trattenemiento de peccerille [1634] In Lo cunto de li cunti, overo Lo trattenemiento de peccerille; Le muse napolitana; Le lettere (Bari: Laterza, 1976), 5-439. 
tion of conteurs and conteuses, however, instigated an authentic cultural revolution as they, in the words of Jack Zipes, institutionalized the genre of the literary fairy tale "as an aesthetic and social means through which questions and issues of civilité, proper behavior and demeanor in all types of situations, were mapped out as narrative strategies for literary socialization, and in many cases, as symbolical gestures of subversion." ${ }^{78}$ The oral folk tale in France had actually not been regarded as worthy enough for being written down and circulated among the literate society until 1690. The conteurs and conteuses thus impelled a definite change in the aesthetic configuration of storytelling whose scope can be summarized by comparing the German terms that effectively express the difference between two major milestones in its modern evolution: the Volksmärchen (popular oral stories) were transformed into Kunstmärchen (artistic or literary stories).

It has been proved beyond any doubt that the fashion of literary fairy tales in France rose from the insightful debates and rhetorical games that flourished in the salons litteraires that were sponsored by French aristocratic women during the reign of Louis XIV. Women aristocrats, who lived restrained in highly ritualized courteous manners, were also deprived of access to schools and universities. In order to overcome the isolation that resulted from these gender codes, they organized social gatherings - which were called salons after the domestic space in which they took place - where they could freely discuss artistic, scientific, philosophical or social novelties, as well as topics such as marriage, love and freedom that were important for them. ${ }^{79}$ Although men and women alike attended these meetings, the latter played the most important role in them. The salonnières chose the guests, programmed their activities and decided the general subject and mood of the debates. The salons represented in this way informal institutions whose cultural and political influence was quite significant. ${ }^{80}$

\section{Zipes, Fairy Tale as Myth, 11.}

79 During the eighteenth century, the term word 'sallon' was used only with architectural connotations. See Louis de Jaucourt, "Sallon," in Encyclopédie ou Dictionnaire Raisonné des Sciences, des Arts et des Métiers (Neufchâtel: Samuel Faulche, 1765) 14:575. The nineteenth century historiography must hence be credited for conferring the term its current social meaning. See Edmond and Jules de Goncourt, La Femme au Dix-Huitième Siècle (Paris: Charpentier, 1882) $44 \mathrm{ff}$.

80 Montesquieu ironically attests the scope of the influence of the salonnières, as he accuses them of having constituted "a state within the state." See Lettres Persanes [1721], ed. Paul Vernière (París: Garnier, 1980) Lettre 104. On the role played by the salons and the salonnières on the rise and consolidation of Enlightenment, see also Dena Goodman, The Republic of Letters: A Cultural History of the French Enlightenment (Ithaca: Cornell University Press, 1994). 
The salons paid high tribute to wit and creativity in conversation. It is not surprising then that toward the last third of the seventeenth century the oral recitation of embellished versions of the old folktales became an acceptable jeux d'esprit in the courtly society. ${ }^{81}$ Generally speaking, the salonnières were also known as précieuses precisely because they tried to develop a précieux manner of thinking, speaking and writing that signaled and celebrated among their peers their unique - and neglected- intellectual talents. ${ }^{82}$ The product of such a manner of thinking - the préciosité - also required smallness in form. The préciosité thus maps the constrained world of upper class women right onto a form which is likewise miniaturized. Just like court life, the préciosité celebrates a form of wit in which a lot is made of a little.

A précieux was thus expected to be capable of transforming even the most banal - for example, the popular contes de vielles ${ }^{83}$ - into something exceptional and dazzling. Under the auspices of the précieuses the oral folktales were transformed, as Claire-Louise Malarte-Feldman observes, into "a society game in literature," that is, "an act of literary prowess" which aspired to push the art of verbal communication up to its ultimate perfection. ${ }^{84}$ It was in this context that, in 1690, Marie-Catherine le Jumel de Barneville, comtesse d'Aulnoy, radically changed the history of literature when she published the first fairy tale in the modern sense of the word, "L'Île de la Félicité," which was part of her novel Histoire d'Hipolyte, comte de Duglas. Madame d'Aulnoy should also be credited for naming the genre, as in 1697 she published a collection of stories titled Les Contes de Fées, which was followed in 1698 by another compilation titled Contes Nouveaux, ou les Fées à la Mode.

In a seminal article on the origins of the literary fairy tale published in 2005, Allison Stedman describes "L'T̂le de la Félicité" as a genuine "Fairy-Tale Manifesto." Stedman contends that, through her path-breaking literary narrative, d'Aulnoy taught "an intimate circle of salon authors to recognize the interpolat-

81 The popularity of fairy tales in Versailles is confirmed, for example, in a letter dated on $\mathrm{Au}$ gust 6, 1677 (among many other sources), in which Marie de Rabutin-Chantal, marquise de Sévigne, informs her daughter, the comtesse de Grignan, about a soirée devoted to discuss the joys and woes of "a princess more beautiful than day" who lived in "a green island" in the company of fairies. See Marie de Rabutin-Chantal, marquise de Sévigne, Lettres, ed. Gérard-Gailly (Paris: Gallimard, 1953-1957), 2:320-321.

82 Zipes, When Dreams Came True, 32.

83 Old wives' tales.

84 Malarte-Feldman, Claire Louise. "Perrault's Contes: An Irregular Pearl of Classical Literature," in Out of the Woods: The Origins of Literary Fairy Tale in Italy and France, ed. Nancy L. Canepa (Detroit: Wayne State University, 1998) 99-128, 114. 
ed fairy tale's capacity to comment on contemporary reality." 85 As a narrative framed within another narrative, "L'Tlle de la Félicité" showed the salonnières that "fairy tales were not merely amusing stories isolated from the reality in which they were created," but "a powerful new literary enterprise" that had the potential "to engage and even to transform the sociopolitical climate of late-seventeenth century France." 86

D'Aulnoy used the characteristic jeu d'illusions of baroque literature ${ }^{87}$ to transform Hipolyte (that is, the protagonist of the novel) into the diegetic author of "L'̂lle de la Félicité" and, even more, to let him use the fairy tale as a comment on his own social situation and personal dilemmas. In the novel, Hypolite, who is in love with Julie, tells her the parallel story of the unfortunate lovers Adolphe and Felicité as a warning about the potentially nefarious consequences of getting obsessed with the conventional notions of virtue and duty. ${ }^{88}$ Stedman claims that d'Aulnoy showed in this way her salon peers that fairy tales were effective instruments for criticizing the prevalent values at Louis XIV's court "without engaging in an overt critique likely to expose the author to censorship or imprisonment."89 I would like to take Stedman's argument one step further by asserting that the most radical political manifesto of the counteses was not uttered in their literary fairy tales, but it was rather embodied in the symbolic signification of fairies themselves.

Fairies were not the only magical creatures in the folktale repertoire, which as everyone knows - is equally crowded, just to mention a few examples, with elves, goblins, ogres, giants and talking animals. Such an astonishing diversity is reflected in Madame d'Aulnoy's marvelous contes. She placed a notorious emphasis on fairies though. The undisputable authority of fairies in the realms of wonder is announced in the very title of her collected stories: in 1697, the expression Contes des Fées could have been taken to mean "tales about fairies." 90 D'Aulnoy characterized fairies with quite different features. They are good or evil, compassionate or vengeful, peaceful or petulant. In "La Chatte Blanche" ("The White Cat") they are described, for instance, as "strange" and cruel crea-

85 Allison Stedman, “D'Aulnoy's Histoire d'Hypolite, comte de Duglas (1690): A Fairy-Tale Manifesto" Marvels \& Tales 19.1 (2005): 32 -53, 33.

86 Stedman, "Fairy-Tale Manifesto," 33.

87 Rousset, La Littérature de l'Âge Baroque en France, 182.

88 Marie-Catherine le Jumel de Barneville, comtesse d'Aulnoy, Histoire d'Hypolite, Comte de Duglas [1690] (Geneva: Slatkine, 1979).

89 Stedman, "Fairy-Tale Manifesto," 46.

90 Marina Warner, From the Beast to the Blonde: On Fairytales and their Tellers (London: Chatto and Windus, 1994), 234. 
tures that possess immense wealth, travel "more magnificently escorted than the great queens of the universe" and are leaded by a fairy called Violente (who certainly lives up to her name). ${ }^{91}$ In "Finette Cendron" ("Ingenious Cinders"), on the contrary, the fairy Merluche is depicted as a mighty, affluent, cunning and generous woman who is honestly concerned with the wellbeing of her goddaughter. ${ }^{92}$ Violente, Merluche and the rest of the fairies, however, have something in common: they are all powerful women.

María del Carmen Ramón Díaz has cleverly encapsulated the profile of D’Aulnoy's fairies in just one phrase: "They are queens in a world where everything is possible." 93 The origins of the French term fée can be traced up to the Latin words fatum (destiny) and fari (to speak). ${ }^{94}$ Fata - the plural for fatum was vulgarized in folklore as fae, a singular feminine noun which designated a female deity - a goddess of destiny - endowed with mysterious magical powers whose source was not connected with any particular religion or mythology. In Madame d'Aulnoy's stories (and those of her précieux cohorts), the fairies vindicate and proudly wield this ancient symbolism of female power over human destiny.

The authority of fairies soon transcended the textual limits of the wondrous stories over which they ruled and, in a unique case of metonymy, was expanded to encompass their authors. In this sense, the literary fairy tales that were created by the précieuses entail a radical exercise of the minor baroque strategy through the identification of their authors with the object of the narration rather than with the position of the narrating subject - an identification that enabled them to challenge the patriarchal hierarchies of the courtly society as fairies who were beyond the power of Louis XIV and his minions by simply acknowledging that both the court and the contes de fées are domains of appearances where reality is always structured on its multiple representations.

In 1698, for example, Madame de Murat published Anguillette, a story whose hero was "a direct descendant of the famous Princess Carpillon and her charm-

91 Marie-Catherine le Jumel de Barneville, comtesse d'Aulnoy, "La Chatte Blanche," in Les Contes des Fées ou Les Fées à la Mode [1697-1698], ed. Adolphe de Lescure (Paris: Librairie des Bibliophiles, 1881), 2:144 and 130-131.

92 D’Aulnoy, "Finette Cendron,” in Les Contes des Fées ou Les Fées à la Mode, 2:3ff.

93 María del Carmen Ramón Díaz, "Las Hadas Modernas en el Cuento Clásico Francés Escrito por Mujeres: ¿Personaje o Autor?,” Thélème: Revista Complutense de Estudios Franceses 16 (2001): 95-107, 101.

94 See Hannon, Fabulous Identities, 16; and Ramón Díaz, "Las Hadas Modernas en el Cuento Clásico Francés,” 101-102. 
ing husband." 95 La Princesse Carpillon was published by Madame d'Aulnoy on the spring of that same year, ${ }^{96}$ so Madame de Murat specifies that the story of the illustrious ancestor of her character "has been told by a modern fairy, even more learned and more polite than those of antiquity." 97 A year later, Madame de Murat developed this analogy further, to the extent of dedicating her Histoires Sublimes et Allégoriques to the "Modern Fairies." According to Murat, the activities of the "Ancient Fairies" (anciennes Fées) were "low and puerile," interesting only to "servants and wet-nurses." The business of Ancient Fairies consisted basically in "sweeping nicely the house, putting the pot on the fire, doing the laundry, rocking the children and putting them to sleep, milking cows, churning butter, and a thousand other miserable things of that kind." The magic of Ancient Fairies was also limited, as they could only make people "cry pearls and diamonds, sneeze emeralds and spit rubies," or transform themselves into other creatures to "frighten children and feeble minds."98 Murat, on the contrary, eulogizes the "Modern Fairies" (Fées Modernes) who personified the conteuses in the following way:

You are only concerned with great things, the least of which are to give wit to those men and women who have none, beauty to the ugly, eloquence to the ignorant, riches to the poor and clarity to the darkest things. You are all beautiful, young, well-formed, nobly and richly dressed and housed, and you live only in the courts of kings, or in enchanted palaces. ${ }^{99}$

This praise of Modern Fairies concludes with Murat identifying her own authorial voice with them: "I offer you some Tales in my own style which, however feeble or incorrect may be, will all the same persuade you that there is no one in the Empire of Fäerie [Empire de Féerie] who is more truly devoted to you." ${ }^{100}$ She situates herself in the kingdom of fairies because some salonnières were actually given that title, Fée. ${ }^{101}$ The fées mentioned in Murat's dedicatory can therefore be read as magical female creatures who performed supernatural

95 Henriette-Julie de Castelnau, comtesse de Murat, Contes de Fées (Paris: Claude Barbin, 1698), 215.

96 See Marie-Catherine le Jumel de Barneville, comtesse d'Aulnoy, La Princesse Carpillon, Conte Nouveau, Tirée des Fées [1698] (Milan: n.p. 1803).

97 Murat, Contes de Fées, 216.

98 Henriette-Julie de Castelnau, comtesse de Murat, Histoires Sublimes et Allegoriques (Paris: Florentin and Pierre Delaulne, 1699), unpaginated preface.

99 Murat, Histoires Sublimes et Allegoriques, unpaginated preface.

100 Murat, Histoires Sublimes et Allegoriques, unpaginated preface.

101 Seifert, Fairy Tales, Sexuality, and Gender in France 1690-1715, 264. 
deeds within the frame of tales; or as storytellers who performed them outside the text by means of narrative. In either case, as Lewis C. Seifert astutely observes, Murat's description of the fées modernes "is both a flattering portrait of the conteuses and an attribution of the powers of fairies to the conteuses - a wish-fulfilment for discursive powers." ${ }^{102}$

In sum, the conteuses were transformed in fées, and fées in turn empowered the counteses, amidst the characteristic baroque destabilization of identities for love of metamorphoses. ${ }^{103}$ Fairies were thus a witty - précieux - artifice for expressing utopian hope in a better future. The first vogue of fairy tales remade folklore in order to create a discursive counter-reality to the rise of Absolutism and the implementation of growing barriers against women in the public sphere. In other words, the first literary fairy tales created "an imaginary compensation for particular lived constraints in the present," as Lewis C. Seifert depicts the reformist - or even revolutionary - substratum that animates the work of the early conteurs and conteuses. ${ }^{104}$ The baroque minor strategy that subverted the hierarchy between essences and appearances was particularly useful for denouncing the wretchedness of Louis XIV's court, where no genuine love, no emancipation, no compassion or tenderness of feeling was suitable. ${ }^{105}$ These legitimate human desires were only possible in the realm of impossible, that is, in the marvelous domain of fairies.

In all of Madame d'Aulnoy's tales, for example, the absolute power over men and women resides in fairies, not in the church or the state. ${ }^{106}$ The fairies determine what the quality of beauty and virtue means, and the women who they protect or instruct exercise political and sexual agency not only beyond the limits of courtly love, but also exceeding the passivity to which women were traditionally condemned. ${ }^{107}$ These narrative features are evident in the two stories that have been mentioned before - "La Chatte Blanche" and "Finette Cendron." In both of them, fairies and women are the ultimate forces that bring about harmony and reformation to corrupted courts.

102 Seifert, Fairy Tales, Sexuality, and Gender in France 1690-1715, 91.

103 On the role of instability and metamorphosis in baroque literature, see Rousset, La Litterature de l'Âge Baroque en France, $181 \mathrm{ff}$.

104 Seifert, Fairy Tales, Sexuality, and Gender in France 1690-1715, 11. Mary Elizabeth Storer holds a similar thesis on the social and cultural milieu that favoured the production of fairy tales in the late seventeenth-century France. See Un Episode Littéraire de la Fin du XVII Siècle: La Mode des Contes de Fées, 1685-1700 (Paris: Champion, 1928) 253.

105 Zipes, When Dreams Came True, 47.

106 Zipes, Fairy Tales and the Art of Subversion, 52.

107 Seifert, Fairy Tales, Sexuality, and Gender in France 1690-1715, 122-125. 
"La Chatte blanche" tells the story of a queen who, unable to resist her desire for fruit growing in a garden belonging to fairies, promises them her unborn daughter in exchange. Later, when the princess refuses to marry the fairies' nephew, they change her into a white cat. ${ }^{108}$ "Finette Cendron" features a malicious queen and a kind-hearted - yet reckless - king who, after unwisely wasting the whole treasure of the kingdom, conceive the fateful plan to abandon their three daughters in a forest. ${ }^{109}$ The conflicted plot of these stories confronts sheer lust for wealth and power as destructive forces while suggesting that the natural flow of feelings that only women can provide is the key to attain and maintain utopia. Both the Cat-Princess and Finette Cendron heal through compassion and sincerity the wounds caused by the struggling upper classes in their quest for recognition and power. The Cat-Princess distributes her wealth among the miserly father and the arrogant brothers of her future husband, thus prompting the reconstitution of their broken family bonds. Finette Cendron forgives both the abandonment of her parents and the mistreatment she suffered from her sisters. Their ideal kingdoms are thus counterposed to the real realm of King Louis, for it is only through the feminine "magic touch" that the basic standards of civility can be maintained. ${ }^{110}$

The imaginative vindication of fairies was, in this sense, a political objection to Absolutism. The wondrous realm of fairies expressed a phantasmatical dream, but such a dream revealed that King Sun's worldly kingdom was no splendid paradise. The conteuses - and, to a lesser extent, the conteurs - resisted through l'Empire de Féerie the power of Louis XIV and the Catholic Church. Jack Zipes interestingly highlights that most of the major fairy-tale writers were in trouble with the hegemonic powers of their time. ${ }^{111}$ Madame d'Aulnoy, for instance, after an unsuccessful attempt to escape an unhappy marriage by incriminating her husband in a lèse-majesté plot, was punished with a brief imprisonment in La Conciergerie and banished from 1670 to 1690, when she finally returned to Paris and established once again numerous contacts among the courtiers. The first published work of Madame de Murat, Histoire de la Courtisane Rhodope (1694), was deemed as a libel against the court, so she was forced her to abandon Paris and settle herself in the provincial city of Loches until the death of Louis XIV, in 1715. Even Charles Perrault, who loyally served the King Sun as Contrôleur des Bâtiments de Roi during the whole life of his protector, Jean Baptiste

108 D'Aulnoy, "La Chatte Blanche," 2:89ff.

109 D’Aulnoy, "Finette Cendron," 2:1 ff.

110 Zipes, Fairy Tales and the Art of Subversion, 26.

111 Zipes, When Dreams Came True, 40. 
Colbert, fell in disgrace in 1683 and subsequently opposed royal cultural policies until his death in 1701.

This is not, however, the whole story of the origin of literary fairy tales. Baroque aesthetics embodied formidable liberating forces, but also instituted - in the insightful words of José Antonio Maravall - a guided and conservative culture. ${ }^{112}$ "What we praise as our classical fairy-tale heritage has a 'dark' side to it," writes Jack Zipes. ${ }^{113}$ This means that while the forgotten conteuses can generally be considered heroines of the baroque minor strategy, under the aegis of the major strategy fairy tales still operate ideologically to indoctrinate individuals so that they will conform to dominant social standards that are not necessarily established in their behalf. There are many subversive signs in the works of the conteuses, but they also compromised themselves under great social pressure to give more expression to male needs and hegemony than to their own. ${ }^{114}$ In the next section I will therefore address how Charles Perrault, the only conteur that surmounted the oblivion imposed by neoclassicism over the seventeenth-century European culture, became the grand master of the major baroque strategy that has entranced the minds of innumerable generations with the promise of opportunity and fulfilment to be had in the future for the little price of serving the interests of the hegemonic elites in the present. ${ }^{115}$

\section{Charles Perrault: our (only) conteur}

Women were particularly active in the primeval development of literary fairy tales. The first generation of fairy-tale writers was formed by seven women and nine men. The conteuses authored two-thirds of the fairy tales published from 1690 to 1715: 74 out of $114 .{ }^{116}$ Only one conteur, however, has been credited with the innovation and early development of French literary fairy tale: Charles Perrault. In 1697 -long after Madame d'Aulnoy had made public "L'T̂le de la Fé-

112 Maravall, La Cultura del Barroco, $107-141$ and 213-242.

113 Zipes, Fairy Tales and the Art of Subversion, 47.

114 Zipes, Fairy Tales and the Art of Subversion, $53 \mathrm{ff}$. One of the two most classic examples of this self-abnegation is "La Belle et la Bête," whose oldest version was published by Madame de Villeneuve in 1740. Belle, as model of humility and obedience saves her father by agreeing to live with Bête - a monster. See Gabrielle-Suzanne Barbot de Villeneuve, La Belle et la Bête [1740] ed. Martine Reid (Paris: Gallimard, 2010).

115 Egginton, The Theater of Truth, 3.

116 Hannon, Fabulous Identities, 11; Seifert, Fairy Tales, Sexuality, and Gender in France 1690$1715,8$. 
licité"- Perrault published his most famous work, the anthology of fairy tales titled Histories ou Contes du Temps Passé (also known as Contes de ma Mère l'Oye because of the label printed on its frontispiece), which includes the following stories: Le Petit Chaperon Rouge ("Little Red Riding Hood"), Les Fées ("The Fairies"); La Barbe Bleue ("Bluebeard"), La Belle au Bois Dormant ("Sleeping Beauty"), Le Maître Chat ou le Chat Botté ("Puss in Boots"), Cendrillon, ou la Petite Pantoufle de Verre ("Cinderella"); Riquet à la Houppe ("Ricky with the Tuft"), and Le Petit Poucet ("Tom Thumb”).

Only Perrault's stories seem to have passed George Orwell's ultimate test of literary merit: historical survival as "an index to majority opinion." 117 How could this happen?

Perrault's contribution to the development of the literary fairy tale is an unusual one because, as Jack Zipes points out, "he is often given credit for creating the vogue when it was really the talented female writers who founded the genre and played a more dynamic role in establishing the fairy tale to subvert the more classical genres." 118 It is true that Madame de Murat's and Madame d'Aulnoy's tales, for example, are usually intricate and contain lengthy courtly discourses about proper manners and virtues, while Perrault's stories are written in a simple style that makes them highly readable texts. This is not, however, a satisfactory explanation for the virtual disappearance of the conteuses' stories from Western cultural horizons. Perhaps, as Zipes suggests, Perrault - who was a member of the Académie Française - has received more attention in Western civilization for a complex of reasons that have not been indifferent to "the fact that he was a male writer with an established name and that he was a more polished and acceptable writer than the female writers of fairy tales - and also all the other men."119

Jacob and Wilhelm Grimm, for example, openly declare their admiration for Perrault in the preface of Kinder und Hausmärchen's first edition (1812-1815). In their view, the superior artistic merit of Perrault resided in his "innocent and simple" style, which allegedly preserved the purity of folk stories. By contrast, they call the conteuses d'Aulnoy and Murat "inferior imitators" of Perrault - despite the fact that it was d'Aulnoy who really inaugurated the vogue of the

117 George Orwell, "Lear, Tolstoy and the Fool” [1947], in The Collected Essays, Journalism and Letters of George Orwell, eds. Sonia Orwell and Ian Angus (Boston: Nonpareil Books, 2000), 4:287-304, 290.

118 Zipes, Fairy Tales and the Art of Subversion, 32.

119 Zipes, Fairy Tales and the Art of Subversion, 32. 
French literary fairy tale. ${ }^{120}$ Regardless their declared commitment to the authenticity of the spirit of the German people, it seems that the Grimm brothers were more concerned with reproducing patriarchal privileges than with actual historical accuracy.

The admiration that the Grimm brothers professed for Perrault has significant social and cultural ramifications. Perrault was a respected polemist who took part on almost every intellectual debate of his time. He was in fact responsible for launching the Querelle des Anciens et des Modernes on January 27, 1687, after his poem Le Siècle de Louis le Grand was read in the Académie Française. Dan Edelstein has briefly recapitulated the spirit of this poem in terms of a binary opposition: Perrault combined in it "a disparaging attitude toward the Ancients" with an "unlimited praise of the Moderns."121 The poem was published later that year and was followed by the four volumes of the Parallèle des Anciens et des Modernes en ce qui Regarde les Arts et les Sciences. Among other educated men, Nicolas Boileau-Despréaux and Jean Racine decided to answer Perrault's challenge and sided with the Ancients. Perrault (obviously) entrenched himself behind the Moderns. Almost every French intellectual figure of the age participated in this fray. Edelstein convincingly argues that the Quarrel is critically important because "it opened up a period of intense self-reflection in which the present was thoroughly studied and contrasted with the past." It was through this process of comparison, he suggests, that "the narrative of Enlightenment was fashioned."122

What does being modern meant for Perrault? In order to fulfil the ideal of modernity, it was necessary for the individual not only to hold a positive attitude toward science, ${ }^{123}$ but also to develop a continuous exercise of galanterie and politeness. ${ }^{124}$ Perrault hence considered fairy tales a useful instrument for educating young men and women in accordance with modern mours. In his preface to Contes en Vers, he compared the fables of the Greeks, the Romans and Jean de La Fontaine with his own fairy tales, claiming that the latter attest to humanity's progress and are more suitable for modern societies because they express Chris-

120 Jacob and Wilhelm Grimm, "Vorrede," in Kinder und Hausmärchen [1812/1815], ed. Heinz Rölleke (Göttingen: Vandenhoeck \& Ruprecht, 1986), 1:v-xxi.

121 Edelstein, The Enlightenment, 38.

122 Edelstein, The Enlightenment, 5.

123 Edelstein, The Enlightenment, 38-39.

124 Charles Perrault, Parallèle des Anciens et des Modernes en ce qui Regarde les Arts et les Sciences [1688-1697], ed. Hans Robert Jauß (Munich: Eidos, 1964) 3:286. 
tian rather than pagan values. ${ }^{125}$ Perrault resorted to the fairy tales for the most part to express his views about young people and to prepare them accordingly for the roles that he idealistically believed they should play in society. Though his tales still courted favor primarily with adults, they also are intended to provide models of behavior for the rearing and schooling of upper-class children. ${ }^{126}$ In Perrault's own words:

\begin{abstract}
As frivolous and bizarre as these Fables can be in their adventures, it is certain that they inspire in Children the desire to be like those whom they see become happy and, at the same time, to fear the miseries into which the wicked fall because of their wickedness. It is praiseworthy of Fathers and Mothers, when their Children are not yet capable of tasting solid truths stripped of all adornment, to let them like them and, if it can be said, to make them swallow them [les leur faire avaler], by inserting them into tales that are delightful and in proportion to the vulnerability of their age. ${ }^{127}$
\end{abstract}

Perrault's modern pedagogic agenda is reflected in the way in which he used in his fairy tales the baroque major strategy as a narrative device. While Madame d'Aulnoy and Madame de Murat ironically affirmed l'Empire de Féerie as their main reality (consequently undermining and subverting the powers of the King and the Church, which had no jurisdiction over fairies), Perrault justified his work as storyteller by claiming that his "trifles of stories" (bagatelles) were not "pure frivolity" because they contained "a useful moral lesson" (une morale utile). ${ }^{128}$ Thus, according to Perrault's explicit authorial intention, behind the delightful appearance of his fairy tales - which are meant to be truthful préciosités - an entire code of conduct is hidden. Perrault himself stressed the baroque origin of his tales by comparing their "playful narrative" (récit enjoué) with an "envelope" which encloses its true meaning: taste (bon gôut), moral (moralité) and accepted standards of behavior (mœurs). ${ }^{129}$

At the time in which Perrault published his tales, the decline of the feudal nobility had led to the formation of an absolutist aristocracy which had gradually abandoned the permissive social codes of medieval courtoisie for more

125 See Charles Perrault, "Préface," in Contes de Perrault [1695-1697], ed. Gilbert Rouger (Paris: Garnier Frères, 1967) 3 ff. It must be noted that Griselidis (1691), Les Souhaits Ridicules ('The Foolish Wishes,' 1693) and Peau d'Ane ('Donkey Skin,' 1694) - published for the first time together in 1695 - have been usually collected in a single volume titled Contes en Vers. See also, by the same author, Parallele, 2:125-136.

126 Zipes, Fairy Tales and the Art of Subversion, 30.

127 Perrault, "Préface," 6.

128 Perrault, "Préface," 3.

129 Perrault, "Préface," 3-7. 
restrictive requirements of appropriate social behavior. The cultural codes that effectively differentiated the aristocracy from the lower social classes were incorporated in the concept of civilité. These codes were referred, for example, to specific dressing styles or the display of proper manners in particular situations, such as eating with cutlery or repressing bodily functions in public. ${ }^{130}$

Such a turn in language - from courtoisie to civilité - is not merely incidental as it implies a transference of distinctive courtly social features to the rising bourgeoisie or, in other words, an expansion of the court to the entire civitas (or to the bourgeois society at least). This cultural movement worked in both directions, as the manners of the old homme courtois were refined to suit the bourgeois virtues of honesty, diligence, responsibility and frugality that, in turn, defined the homme civilisé. This way, a series of style conventions, rules of treatment and standards of expression of emotions were constituted in the common heritage of both social classes.

Charles Perrault's fairy tales were consciously written as devices for promoting and spreading this aristocratic-bourgeois civilité. The standards of properly acceptable behavior provided by Perrault's stories are clear-cut differentiated on gender bases: domestic industry and self-sacrifice for girls; courage, competitiveness and acquisitiveness for boys. ${ }^{131}$ For Perrault, the ideal femme civilisée should be like Cendrillon. ${ }^{132}$ In Perrault's version of the story, a wealthy widower marries a proud and haughty woman as his second wife. She already had two daughters, who were equally vain and selfish. He also had a beautiful young daughter by his first wife, who was a girl of unequalled virtuousness and sweet temper. Unfortunately, virtue did not pay in this case: the stepmother and her daughters forced her into servitude. With the help of her Fairy Godmother, however, Cendrillon married the Prince of the land. The first moral of the story indicates that a woman must be endowed with equal doses of beauty (beauté) and gentle grace (bonne grâce) in order to ensure a convenient marriage. ${ }^{133}$ The second moral of the story interestingly mitigates the first one by suggesting that, even though it is a great advantage to have "intelligence, courage, good breeding, and common sense," without the blessing of a godfather or a godmother these talents may fail to bring success. ${ }^{134}$

130 Norbert Elias, The Civilizing Process [1939], trans. Edmund Jephcott, eds. Eric Dunning et al. (Oxford: Blackwell, 2000), $47 \mathrm{ff}$.

131 Zipes, Fairy Tales and the Arts of Subversion, 39.

132 Perrault, "Cendrillon," in Contes, $157 \mathrm{ff}$.

133 Perrault, "Cendrillon,” 164.

134 Perrault, “Cendrillon,” 164-165. 
Perrault likewise asserts that the homme civilisé requires industry (industrie), wit (savoir-faire) and suitable dress (habit), countenance (mine) and youth (jeunesse), in order to achieve success as the Maître Chat did. ${ }^{135}$ The actual hero of Perrault's story is Maître Chat, who needs to dress the proper implements (a pair of boots and a pouch) to serve his master. ${ }^{136}$ The cat is, as Jack Zipes argues, the epitome of the educated bourgeois secretary who serves his master with both devotion and diligence. ${ }^{137}$ He has such correct manners and wit that he actually impresses (and deceives) the king, while using his intelligence to dispose of an ogre and arrange a royal marriage for his low-born master. He can therefore end his career by becoming a grand seigneur who never again runs after mice but for his diversion. In Perrault's understanding of aristocracy, to become a noble means precisely to cease considering eating as a matter of survival and regard it instead as a pretext for entertainment. ${ }^{138}$

Perrault's stories thus display a humorless series of instructions to achieve worldly success behind a façade of witty and elegant humor. Their structure follows the lines of what I have been calling the baroque major strategy, which involves the promise of presence just beyond the veil of mediation. ${ }^{139}$ The pedagogical intention that moves the stories can be dismembered in two moments: first, the narrative shows the appearances of social life that hamper the path toward power and recognition; second, the morals indicate the means to unveil these appearances in order to achieve real power and recognition.

Perrault is a key historical figure in the institutionalization of the fairy tale as a normative discourse inscribed in Western nomoi. He really is our conteur: his voice has transcended the salons and is still heard in our everyday life. His main legacy is the enforcement of a patriarchal code of civilité to the detriment of women, even though women were originally the major writers of fairy tales. ${ }^{140}$ His stories, however, cannot entirely escape the ambivalence of the baroque fairy magic. We can undoubtedly read the feats of Maitre Chat, for instance, as mirror

135 Perrault, "Le Maître Chat ou le Chat Botté," in Contes, 142.

136 Perrault, "Le Maître Chat ou le Chat Botté," 137.

137 Zipes, Fairy Tales and the Art of Subversion, 41.

138 Louis Marin, "Puss-in Boots: Power of Signs. Signs of Power," Diacritics 7.2 (1977): $54-$ 63, 63.

139 Egginton, The Theater of Truth, 40.

140 Curiously, Perrault's three verse tales, along with the poem titled Apologie des Femmes (1694) were intended as a defense of women against Boileau's misogynist satires. Perrault tried to justify the convenience of exercising only just and limited authority over women. His works thus expose the discursive setup embedded in patriarchal ideologies: whenever they pretend supporting the emancipation of women, they actually reinforce their oppression as they resist acknowledging the equality between womankind and mankind. 
images of the opportunistic development of the haute bourgeoisie in the late seventeenth-century France. Nevertheless, this is not the only possible reading of the tale. We can alternatively acknowledge what the minor baroque strategy suggests, that is, that the promise of purity behind the veil of appearances is itself already corrupted by the very distinction that gave birth to it. We can then choose to follow this minor strategy and turn the story of Maitre Chat upside down, transforming it into a distressing critique of a world in which survival depends on absolute obedience to a master, the neat clothes we wear and our capacity for cheating, lying and killing when necessary for our purposes.

In this sense, Ernst Bloch contends that there is always a utopian surplus even in the deceptive and repressive dominion of ideology. ${ }^{141}$ As readers, we are the ultimate owners of literary fairy tales. How could we otherwise explain the manifold versions of the story of the shrewd cat that enables disadvantaged or abused young men to attain wealth and power, as it has been successively told by Straparola, ${ }^{142}$ Basile $^{143}$ or Madame d'Aulnoy, ${ }^{144}$ among other writers and storytellers? Maître Chat -as the rest of Perrault's stories- is bigger than its literary author. A radical baroque reading of Perrault's baroque tales could therefore let us say about him what Jean-Jacques Rousseau once said about Niccolò Machiavelli: "He professed to teach kings; but it was the people he really taught."145 Rousseau regarded Il Principe as a book for Republicans. ${ }^{146}$ In the perennially contested domains of nomos, the combined forces of the merveilleux and the baroque minor strategy can similarly render Histories ou Contes du Temps Passé a socialist and feminist book.

\section{Epilogue: Tlön, Uqbar, Orbis Tertius ... and Pinocchio}

Jorge Luis Borges' non-fairy short story titled “Tlön, Uqbar, Orbis Tertius” is probably one of the best contemporary examples of the continuity of the baroque

141 Bloch, Ernst. Das Prinzip Hoffnung. [1954-1959] (Frankfurt am Main: Suhrkamp, 1977), 1:174ff.

142 Constantino Fortunato.

143 Cagliuso.

144 La Chatte Blanche.

145 Jean-Jacques Rousseau, Du Contrat Social ou, Principes du Droit Politique [1762], in Du Contrat Social, precedé de Discours sur l'Économie Politique et de Du Contrat Social, Première Version, et suivi de Fragments Politiques, ed. Robert Derathé (Paris: Gallimard, 2010) 231.

146 Jean-Jacques Rousseau, Du Contrat Social, 231. 
minor strategy and, accordingly, of the permanence of the Baroque as a problem of thought across different epochs. In this story, Borges and one of his closest friends, Adolfo Bioy Casares, comment an encyclopedia article about a mysterious country called Uqbar, ${ }^{147}$ which is the first indication of a massive conspiracy of intellectuals to imagine (and thereby create) a world called Tlön with its own physical and metaphysical laws in which the epics and legends of Uqbar's literature are set. It is eventually revealed that Tlön is the invention of a secret society dating to the seventeenth century. While the fictional Borges and several of his academic colleagues pursue interesting speculations about the epistemology, language, and literature of Tlön, the rest of the world gradually begins to adopt the Tlönic culture. In the epilogue set in 1947, the Earth is in the process of becoming Tlön. ${ }^{148}$

In Borges' neobaroque fiction a world is imagined, and reality gives way. This is the very essence of the Baroque: the fading of frames, the loss of bearings when looking upon a representation. ${ }^{149}$ This is also the domain of fairy tales in more than one sense. In the article devoted to the historical Baroque in the Encyclopaedia of the Early Modern World, Philip L. Sohm notes while discussing the modern relevance of baroque aesthetics that "[i]n Carlo Collodi's Pinocchio (1883) the metamorphosized bamboccio is sent off to an enchanted house of mirrors, the 'Casa dei Barocchi,' where men are transformed into asses, and it is in this unlikely place that Pinocchio finds his true path." 150 This could actually be quite a suggestive motif about the connections between the Baroque and the fairy tale tradition, except for one detail: it is blatantly false. Unless I am the one with a mistaken print of the book (I must admit that this is a world of untrustworthy appearances), in my version Pinocchio is never sent to an enchanted house of mirrors: he voluntarily departs with his friend "Lucignolo" (wick) to the "Paese dei Balocchi" (Land of Toys) where, after five months of "cuccagna" (good time) without books, schools or teachers, he is transformed into an ass. ${ }^{151}$

Fairies have never abandoned their baroque scenarios: when trying to comprehend them, one moment you can be informing yourself about their prevalent aesthetics in the seventeenth century, and the next moment you have been invol-

147 Jorge Luis Borges, “Tlön, Uqbar, Orbis Tertius” [1941], in Obras Completas, ed. Carlos V. Frías (Buenos Aires: Emecé, 1996) 1:431.

148 Jorge Luis Borges, “Tlön, Uqbar, Orbis Tertius,” $440 \mathrm{ff}$.

149 Egginton, The Theater of Truth, 105-106.

150 Philip L. Sohm, "Baroque," in Europe 1450 to 1789: Encyclopedia of the Early Modern World, ed. Jonathan Dewald (New York: Charles Scribner’s Sons, 2004) 1:227-230.

151 Carlo Collodi, Le Avventure di Pinocchio: Storia de un Burattino (Florence: Felice Paggi, 1883), $163 \mathrm{ff}$. 
untarily cast into one of Borges' stories. What Sohm's (neo)baroque appropriation and recreation of Pinocchio's adventures shows us -surprising as it may be to find it in an encyclopedia - is that literary fairy tales are a living tradition still open to alternatives and, therefore, capable of fostering utopia. Let us think, for instance, in the subversion of the Perraldian corpus accomplished by Angela Carter in her much quoted and celebrated anthology of contemporary fairy tales titled The Bloody Chamber. ${ }^{152}$ The variations of classical fairy tales carried out by Carter have been possible because the conteuses and the conteurs could not impose any ideological closure over their creation: their stories are being told and (re)told today, and they will undoubtedly be told again tomorrow, in a play of desire and anticipation that will go on as long as human beings remain hopeful about a future that per definitionem is not already finished, but always involved in the process of becoming.

Walter Benjamin pointed out that oral folktales embodied an early call of humanity to oppose insolence and craftiness against the oppressive forces of myth. Benjamin compellingly argues that fairy tales have remained until today as guidance for children because they counselled once the entire humanity. These first teachers of humanity, suggests Benjamin, nowadays have become the governors of our ingenuity under its most constructive and encouraging connotation, that is, as a word that can either be tracked back to the Latin expressions ingenium (mind, intellect) or ingenuus (born free). ${ }^{153}$ As folk and fairy tales speak to our desires to escape the dull and frequently cruel confines of the ordinary, Ernst Bloch similarly perceived in them an effective utopian anticipation of the "earliest kind of Enlightenment" that relies upon the three main imperatives of Fäerie: "consider yourself as born free and entitled to be totally happy, dare to make use of your power of reasoning," and "look upon the outcome of things as friendly." 154

I will conclude this essay, after Benjamin's and Bloch's reflections, by dubbing the French baroque literary fairy tales as "hodiernos," a beautiful old-fashioned Spanish adjective which means "that which concerns today." The meaning of hodierno is slightly different from that of "moderno" (modern), which denotes

152 Angela Carter, The Bloody Chamber and Other Stories [1979] (London: Vintage, 2006). 153 Benjamin, Walter. "Der Erzähler: Betrachtungen zum Werk Nikolai Lesskows" [1936], in Gesammelte Schriften (Frankfurt am Main, Suhrkamp, 1991) 2-2:438-465, 457-458.

154 Ernst Bloch, "Das Märchen geht selber in Zeit," in Die Kunst, Schiller zu sprechen (Frankfurt am Main: Insel, 1969), 14.

* I am deeply grateful to Desmond Manderson for his enlightening comments on the first draft of this essay (which was written a long time ago), and to Mariana Romero-Iribarne for keeping me constantly aware of the power of fairies, both good and evil, over young minds. 
"that which belongs to the times of the speaker or a recent epoch." Fairy tales continue to concern us today because we create justice day after day: in this sense, anyone can transform an individual into a toad by acting unjustly, or conversely transform a toad into a human being by recognizing his or her inherent dignity. The baroque literary fairy tale, in sum, concerns us today because it is worth re-telling: even the mocking path of Pinocchio, after its last (minor) baroque turn, can be revealed to be our true path to justice amidst the instable boundaries of nomos. 
Brought to you by | University of Wollongong Library 